\title{
The Importance of Needs Assessment for the Implementation of E-Learning in a Language Program
}

\section{S. T. Nugraha, S. Suwandi, J. Nurkamto, and K. Saddhono}

Doctoral Program of Indonesian Language Education, Faculty of Teacher Training and Education, Sebelas Maret University, Surakarta, Central Java, Indonesia

\section{Abstract}

This study describes the importance of needs assessment in the teaching of Indonesian Language as a Second/Foreign Language e-learning program. Needs assessment is one of the main investigative tools used by institutions for the identification of actual needs, gaps, and hidden parts of the system and other activities. From this investigation, curriculum developers obtain various pieces of information on

Corresponding Author:

S. T. Nugraha

setyatrinugraha@

student.uns.ac.id

Received: 6 April 2018

Accepted: 3 May 2018

Published: 26 July 2018

Publishing services provided by Knowledge $\mathrm{E}$

(c) S. T. Nugraha et al. This article is distributed under the terms of the Creative Commons

Attribution License, which

permits unrestricted use and redistribution provided that the original author and source are credited.

Selection and Peer-review under the responsibility of the ISLLE 2017 Conference Committee.

\section{G OPEN ACCESS} linguistics background, learning style preferences, teaching strategies, students' motivations, and also students' commitment in their involvement in the e-learning language program. Needs assessment will help teachers to analyze the learning materials, content, and media for their e-learning programs, and in turn will be instrumental in developing their e-learning strategies. A needs assessment can also provide information about the technology and other support services needed for the e-learning programs. Through a comprehensive needs assessment process, an institution can establish e-learning goals.

\section{Keywords: e-learning, needs assessment program}

\section{Introduction}

Needs assessment is a systematic approach to assessing the knowledge, abilities, interests, or early behavior of learners or groups of learners before they are enrolled in a learning program. Needs assessment is an important process that is needed so that learners can verify their level of knowledge and skills, clarify their interests and thoughts, and determine their learning habits and choices when enrolling in a particular learning program. In addition, needs assessment is also important for the learning program developers or curriculum developers to be able to know and describe the competency gap that is already possessed or mastered by the learners in terms of 
what is needed during the times they follow the language program later on. The reason underlying this vast study of needs assessment is the convincing fact that needs assessment is the foundation or basis for decision-making related to the curriculum $[1,2]$. Through this needs assessment stage, curriculum policymakers will acquire the learners' data, objectives, learning projections, learning style, and learning strategy preferences, as well as the language situation that they will enter so that the curriculum/program developers can develop the curriculum components or language training programs effectively and systematically $[3,4]$

E-learning is an innovative approach to delivering a well-designed, learnercentered, interactive learning process facilitated by an open, flexible, and distributed learning environment by utilizing a variety of digital technology or information and technology as well as communication tools [5-7]. As an innovative approach, elearning demands a paradigm shift not only from the learners, but also from the teachers, instructors, trainers, administrators, technicians, and other support staff. In e-learning implementation and in an effort to create an open, flexible, and distributed learning environment, the learning program or curriculum developers should explore important issues related to the various dimensions of e-learning environments. To achieve this goal, a comprehensive needs assessment is required [8].

To create a learning environment with the e-learning system, there are eight dimensions that have to be observed in order to realize an effective process. These eight dimensions of e-learning include (1) institutional, (2) pedagogical, (3) technology, (4) interface design, (5) evaluation, (6) management, (7) source support, and (8) ethics. These eight dimensions have their respective subdimensions. Each of these subdimensions has specific aspects of the e-learning environment. First, the institutional dimension is a dimension that deals specifically with matters related to administration, academics, and service affairs to the learners that are associated with e-learning. Second, the pedagogical dimension in this e-learning refers to the learning and teaching process that focuses directly on the content analysis, audience, objectives, media, approaches, design, and learning strategies. Third, the technology dimension is related to technology and infrastructure issues including infrastructure planning as well as hardware and software provision. Fourth, the interface design dimension refers to all aspects that are seen and perceived/the learners' sense of presence in the elearning program. Fifth, the evaluation dimension for e-learning includes assessment for the learners and evaluation for the instructional programs and learning environments. Sixth, the management dimension refers to the management of the learning environment and information distribution. Seventh, the source support dimension 
is related to providing the online support and resources necessary for a meaningful learning to be realized. Eighth, the ethics dimension focuses on e-learning that is associated with social and political influences, cultural diversity, bias, geographical diversity, learners' diversity, technological ethics, and things that are related to legal issues. These eight dimensions and subdimensions make their respective contributions to the implementation of e-learning from the stages of planning, design, production, evaluation, delivery and maintenance, instruction, and marketing $[5,9,10]$. These eight dimensions are the dimensions that will have to become an important element in the design of needs assessments when the e-learning program is going to be organized.

This needs assessment process will also be a kind of "bridge" to address the gaps existing in the language training syllabus with the learners' needs. To that end, the curriculum developers have to perform a thorough, carefully considered, and wellplanned needs assessment. They should also periodically evaluate, determine, or decide whether the running program is still accommodating the learners' needs or has deviated from the expectations of the learners $[11,12]$. This is in line with what was proposed by Richards i.e. that in language teaching, needs assessment is the stage of determining the learners' needs in the language program as well as simultaneously structuring those various needs according to the priority of the learners [13]. From this stage, it can be seen that the process of selecting and evaluating a variety of information has been conducted since the beginning of the curriculum development. The subjective and objective information is gained through questionnaires, tests, interviews, and observations $[4,14]$.

In the context of Indonesian Language Learning for Foreign Speakers, needs assessment is an important investigative stage that is conducted by an institution or a language training provider to identify the needs and actual gaps of the learners. From this investigation, curriculum developers or learning programs developers will obtain a variety of information regarding the purpose, content, linguistic background, learning style preferences, teaching strategies, the motivation of the learners, outcomes, and also the commitment of the learners when enrolling in a language program. This paper will present the results of a case study on the importance of needs assessment in the implementation of an Indonesian for Foreign Speakers e-learning program.

\section{Methods}

This study is a case study on the implementation of needs assessment in an e-learning program of Indonesian language learning for foreign speakers. The purpose of this case 
study is to obtain a description of the implementation of needs assessment as one of the important stages of the e-learning implementation at one of the language training institution providers in Yogyakarta.

These data were obtained through interviews and document study. Interviews were conducted for the program developers, teachers, IT support, and the research and development (R\&D) team. In these interviews, typically topics were clearly identified so that the direction of the interview was focused. The focus of the interviews with the informants was to obtain information related to the learning process by using certain BIPA e-learning programs, existing technology conditions, users' competence, and the supporting or inhibiting aspects of learning with the BIPA e-learning program.

The document study was conducted to determine the quality of the documents for the needs analysis, lesson plans, teaching materials, and evaluation instruments of the BIPA e-learning program.

\section{Results}

The needs assessment process was carried out in the institution where this study was conducted by referring to the principle that e-learning is a form of learning that can as best as possible "transfer" the real class into the virtual classroom with adequate technology packaging. Based on this principle, the institution conducted the needs assessment to develop a program plan by filtering information from the learners in the form of personal data, proficiency level, and early language competence, with an emphasis on language skills to be improved, and specific preferences related to the background of the learners. These things were listed on the registration form that the learners had to fill in before enrolling themselves in the program.

Based on the interview, the needs assessment was mainly conducted by the teachers and the R\&D division. Needs assessment conducted by the teachers was in the form of verbal questions and answers related to the initial proficiency in the language, the level to be entered, and the topics that interested the learners. Teachers also explore information related to the technical proficiency of the learners as an initial prerequisite for participating in an e-learning program, including the ability or capacity of the Internet at the learners' premises to ensure that the e-learning process can run smoothly. The needs assessment conducted by the R\&D division was focused on the options for the learning materials and media that are going to be used in the program that the learners will take. Information extracted from the needs assessment process is the source for developing the syllabus. 
In relation to the curriculum, with no comprehensive needs assessment, it was found that the curriculum development of the e-learning program was still experiencing problems due to the ungrouped competence profile to be upgraded and the inaccuracy of the level placement. With such conditions, the e-learning curriculum is equated with the curriculum of the onsite learning whereas the dimensions of e-learning differ from the dimensions of regular learning. The step taken by the institution is more related to the renewal of only one of the components of the curriculum, which is the learning materials. Every learner who is enrolled in the e-learning program is offered new learning materials by adjusting them to the interest of the learner. Other curriculum components are not comprehensively updated. This will certainly have an impact on the achievement of the learning objectives.

Data analysis obtained from the interviews and document study shows that the needs assessment conducted at the institution where this study takes place has not covered the overall dimensions of e-learning. Only some of the eight dimensions of elearning, as described by Khan, i.e. (1) institutional, (2) pedagogical, (3) technology, (4) interface design, (5) evaluation, (6) management, (7) source support, and (8) ethics, were covered $[9,10]$. Those dimensions are pedagogical, technology, and interface design. In addition, not all subaspects in the three dimensions are covered in the needs assessment process. As a result, the profile of the learner candidate is still incomplete and this has an impact on the preparation of a syllabus, which is less comprehensive. This impact will certainly lead to a chain effect on the subsequent learning process that appears on the number of improvisations in the learning process and the shifting focus of learning or language skills that are going to be mastered.

The limitations of information obtained from a less comprehensive needs assessment make the learning process not optimal in relation to the "sense of presence," which becomes the core of learning with an e-learning system. The interface design models that are designed become limited so that the exploration of language activities that are appropriate with the learning styles and learning strategies are also not diverse. This can certainly be overcome by providing various programs or applications that can be implemented in the e-learning system so that in addition to face-to-face encounters with the teachers, there are other programs or applications that can be accessed by the learners independently to improve their language competence. 


\section{Conclusion}

Needs assessment is an important process in e-learning program development because it will help the learners and training providers and/or language training in designing the planning, implementation, and assessment of the learning program. Needs assessment in the organization of e-learning will produce accurate, meaningful, and useful information when it includes the institutional, pedagogical, technology, interface design, evaluation, management, source support, and ethics dimensions. With these eight dimensions included in the needs assessment process, the curriculum or the BIPA e-learning program developers can provide assurance that the learning process that will be followed by the learners can take place according to the objectives and with an effective process as well as with outcomes that are appropriate to the initial planning.

\section{References}

[1] Soruc A: The Role of Needs Analysis and Language Program Renewal Process. Mevlana Int J Educ. 2012; 2 (1): 36-47.

[2] Barbazette J: Training Needs Assessment: Methods, Tools, and Techniques. San Francisco: John Willey \& Sons; 2006.

[3] Paci M: Needs Analysis and Environment Analysis: Designing an ESP Curriculum for the Students of the Polytechnic University of Tirana. Journal of Educational and Social Research, 2013; 3(7): 425-430.

[4] Chegeni N, Chegeni N: Language Curriculum Development and Importance of Needs Analysis. Department of English, Islamic Azad University, Iran. ELT Voices-India. 3 (4), 1-13.

[5] Khan BH: A Comprehensive E-learning Model, Je-LKS, Journal of e-learning and Knowledge Society. 2005. 1(1): 33-44.

[6] Arkorful V, Abaidoo N: The Role of E-learning, the Advantages and Disadvantages of Its Adoption in Higher Education. International Journal of Education and Research. 2014; 2(12): 397-410.

[7] Fee K: Delivering E-learning: A Complete Strategy for Design, Application, and Assessment. London: Kogan Page; 2009.

[8] Azimi HM, Rahmani R: Importance of Needs assessment of Implementation of Elearning in College of Education, IJICT. 2013; 3 (5): 377-382.

[9] Khan BH: E-learning Quick Checklist. Hershey: Information Science Publishing; 2005. 
[10] Khan BH: Managing E-learning Strategies: Design, Delivery, Implementation, and Evaluation. Hershey: Information Science Publishing; 2005.

[11] Jackson J. 2005. An Inter-university, cross-disciplinary analysis of business education: Perceptions of business faculty in Hong Kong. English for Specific Purposes. 2005. 24(3), 293-306.

[12] Altschuld JW, Eastmond Jr JN: Need Assessment KIT-Book 2,Phase I: Getting Started. Thousand Oaks: SAGE Publications, Inc.; 2010.

[13] Moore JL, Dickso-Deane C, Galyen K: e-learning, Online Learning, and Distance Learning Environment: Are They the Same?. The Internet and Higher Education. 2011; 14(2): 129-135.

[14] Kaewpet C: A Framework for Investigating Learning Needs: Needs Analysis Extended to Curriculum Development. Electronic Journal of Foreign Language Teaching. 2009; 6(2): 209-220. 